\title{
Desulphurization of dibenzothiophene by different bacteria: A case study on model compound
}

Aniruddha Kumar ( $\square$ aniruddhakumar21@gmail.com )

Babasaheb Bhimrao Ambedkar University https://orcid.org/0000-0003-0553-459X

\section{Asha Lata Singh}

Banaras Hindu University

\section{Prakash K Singh}

Banaras Hindu University Faculty of Science

\section{Research}

Keywords: Dibenzothiophene, Desulphurization, GC-Mass spectrometry, 2-hydroxy biphenyl, Rhodococcus sp.

Posted Date: May 20th, 2020

DOI: https://doi.org/10.21203/rs.3.rs-29396/v1

License: @ (i) This work is licensed under a Creative Commons Attribution 4.0 International License. Read Full License 


\section{Abstract}

Bacterial strains are successfully employed to desulfurize dibenzothiophene which may be determined by chromatography, HPLC and GC-Mass spectrometry. Strains of Ralstonia sp ., Pseudoxanthomons sp. and Rhodococcus sp. were used in the present investigation. Only Rhodococcus sp. was able to convert dibenzothiophene (DBT) into 2-hydroxy biphenyl (2-HBP). Gibb's assay blue colour indicates the conversion of DBT into 2-HBP and brown colour indicates complete consumption of DBT by bacteria. After two days of bacterial treatment, there was no further removal of DBT. Conversion of DBT into 2-HBP was monitored through HPLC for six days of entire experiment.

\section{Introduction}

Dibenzothiophene (DBT) is one of the main contaminants occurring in the organic sulphur compounds in the hydrocarbons of fossil fuels and polycyclic aromatic hydrocarbons (PHAs) (Max Nestler, 1974). It is present as an internal part of the coal matrix, covalently bound in complex form (Marinow et al. 2011). It may be used as a typical model compound for desulphurization studies because of its high boiling point, recalcitrant and resistance to conventional methods of organic sulphur compound (OSC) removal (Mishra et al. 2014; Borzenkova et al. 2013).

DBT is highly toxic and its inhalation leads to lung disorders in human and causes inflammation if it comes in contact with skin (Mishra et al. 2016). During its refining, more amount of sulphur oxides may lead to the acid rain, pollute the environment, biosphere and may cause other health issues (Tailleur et al. 2005 and Ollivier 2005). Heterocyclic compound and its derivatives may persist up to three years after an oil spill and cause severe environmental implications (Gundlach et al. 1983).

Sulphur removal from coal has become a subject of extensive research and it is being given more impetus during last one decade (Singh and Singh 2010; Singh et al. 2012, 2013, 2018; Kumar et al. 2019). The presence of sulphur compounds in coal and oil is a limiting factor for their industrial use because of environmental implications (Demirba 2002). Sulphur dioxide combines with rainwater in the air to form sulphuric acid. Subsequently it falls in form of acid rain which affects agriculture and harms the ecological balance (Ayhan 2004).

Biodesulphurization of organic sulphur compounds is performed in ambient conditions without lowering the calorific value of coal and oil (Soleimani 2007). Strains of several bacteria such as Pseudomonas, Gordonia, Paenibacillus and Mycobacterium have been found to be useful for the desulphurization activity. These microorganisms adopt biochemical mechanism, such as Kodama and $4 S$ pathways, to metabolize various aromatic sulphur compounds. Strain converts dibenzothiophene (DBT) into 2Hydroxybiphenyl (2-HBP). DBT serves as the source of sulphur for biomass and generates 2Hydroxybiphenyl in the broth and helps in proper growth of the biomass (Kayser et al. 1993; Oldfiel et al. 1997). Several bacteria are reported to desulphurize DBT following $4 S$ pathway like Rhodococcus erythropolis IGTS8; (Kilbane 1990). Other DBT desulphurizing microorganisms, mainly mesophilic and 
few thermophilic, have also been identified which include Rhodococcus erythropolis D-1 (Ohshiro et al. 1999), Mycobacterium sp. Strain G3 (Nekodzuka et al. 1997), Gordonia sp. CYKS1 (Rhee et al. 1998), Pseudomonas delafieldii R-8 (Luo et al. 2003), Microbacterium sp. ZD-M2 (Zhang et al. 2005), Bacillus subtilis WU-S28 (Kirimura et al. 2001), Mycobacterium pheli WU-F1 (Furuya et al. 2001), Gordonia alkanivorans RIPI90A (Mohebali et al. 2007), Pantoea agglomerans D23W3 (Bhatia and Sharma 2010) and Sphingomonas subarctica T7b (Gunam et al. 2013).

In the present paper an attempt has been made to compare the desulphurization activity of the bacterial strains of Pseudoxanthomonas sp., Ralstonia sp. and Rhodococcus sp. These bacteria are able to use various organic sulphur compounds as source of sulphur. In this experiment, Dibenzothiophene has been used as a sulfur compound which is often present in sulphur rich coals.

\section{Materials And Methods}

\subsection{Chemicals and Reagents}

DBT (99\% purity), 2-HBP (99\% purity), Peptone type-1 (M.B grade), Yeast extracts powder (M.B grade) and glucose, were procured from HiMedia Laboratories Pvt Ltd. (Mumbai, India). Potassium dihydrogen phosphate $\left(\mathrm{KH}_{2} \mathrm{PO}_{4}\right)$, Ammonium chloride $\left(\mathrm{NH}_{4} \mathrm{Cl}\right)$, Magnesium chloride hexahydrate $\left(\mathrm{MgCl}_{2} \cdot 6 \mathrm{H}_{2} \mathrm{O}\right)$, Disodium Hydrogen Phosphate $\left(\mathrm{Na}_{2} \mathrm{HPO}_{4}\right)$, Ethyl Acetate and Methanol $\left(\mathrm{CH}_{3} \mathrm{OH}\right)$ were purchased from Merck Laboratories Pvt Ltd., Germany. All the chemicals were of analytical grade, commercially available and were used without further purification.

\subsection{Culture Media and growth conditions}

For the growth of bacteria and treatment of DBT, two different media are prepared and the sulphur free Basal salt medium (BSM) is used for treatment having a composition of $0.2 \mathrm{~g}$ glucose, $0.24 \mathrm{~g} \mathrm{Na}_{2} \mathrm{HPO}_{4}$, $0.577 \mathrm{~g} \mathrm{KH}_{2} \mathrm{PO}_{4}, 0.2 \mathrm{~g} \mathrm{NH}_{4} \mathrm{Cl}, 0.02 \mathrm{~g} \mathrm{MgCl}_{2} .6 \mathrm{H}_{2} \mathrm{O}$ per $100 \mathrm{ml}$ of double distilled water and $\mathrm{pH}$ maintained at $7.0 \pm 0.2$. For proper bacterial growth, $0.5 \mathrm{~g}$ peptone, $0.5 \mathrm{~g}$ yeast extracts and $1.0 \mathrm{~g}$ of glucose per $100 \mathrm{ml}$ of double distilled water were added in the nutrient broth. The entire broth medium was sterilized by autoclave. The stock solution of (100 ppm) DBT and 2-HBP were prepared in methanol.

\subsection{Bacterial Isolation, Identification and Maintenance}

Three different bacterial strains were isolated from different sources. Pseudoxanthomonas sp., Ralstonia $\mathrm{sp}$. were isolated from hydrocarbon contaminated soil and coal field sample. The detailed process has been discussed by Singh et al. (2012). Rhodococcus sp. was isolated from soil sample collected from Chitrakoot District, U.P, India. A gram of powdered sample was added to $10 \mathrm{ml}$ double distilled water and after thorough stirring it was filtered. One $\mathrm{ml}$ filtered water was diluted hundred times with double distilled water and was inoculated on basal salt containing solid agar plates at ambient temperature. Colonies were seen to develop on the solid agar plates within twenty four hours, which were picked up and inoculated in liquid basal salt media. The bacterium was identified as Ralstonia sp., Pseudoxanthomonas 
sp. at Institute of Microbial Technology (IMTECH), Chandigarh, India. The identification of Rhodococcus sp. was carried out at the Indian Institute of Vegetable Research (IIVR), Varanasi, U.P., India.

\section{Analytical Methods}

\subsection{Growth estimation of bacteria}

Bacterial cell growth was monitored by measuring optical density of the culture at $660 \mathrm{~nm}$, using spectrophotometer (UV/VIS), model HITACHI U-2900.

\subsection{HPLC analysis}

High-performance liquid chromatography (HPLC) was used for the quantitative assay of DBT (retention time - $7.49 \mathrm{~min}$ ) and 2-HBP (retention time - $1.43 \mathrm{~min}$ ) in the dodecane phase. HPLC was performed on HPLC Model Water 600 controller, 717 plus autosampler, Waters 2988 photodiode array detector. The separation was performed with water spherisorb ${ }^{\circledR} 5.0 \mathrm{~m}$ ODS $24.6 \mathrm{~mm} \times 250 \mathrm{~mm}$ column. An isocratic elution was carried out with $75 \%$ methanol and $25 \%$ water at flow rate of $1.5 \mathrm{ml} / \mathrm{min}$ and the detection was realized with Waters 2988 photodiode array detector fixed at $254 \mathrm{~nm}$ wavelength. HPLC quantification of DBT and 2-HBP was performed by comparing with standard curve using a series of dilution of these pure compounds.

\subsection{UV spectrophotometer and Gibbs assay}

Ralstonia sp., Pseudoxanthomonas sp. and Rhodococcus sp. bacterial species were grown in LB medium at $30{ }^{\circ} \mathrm{C}$. The optical density was maintained at 2.0 at $660_{\mathrm{nm}}$. The bacteria were harvested by centrifugation and re-suspended in BSM medium for desulphurization.

Gibb's assay was performed for determining the conversion of DBT to phenolic compounds by isolates as per Oldfield et al. (1997). $150 \mu \mathrm{L}$ of the reaction mixture is transferred into a micro plate and mixed with $30 \mu \mathrm{L}$ of $1 \mathrm{M} \mathrm{NaNCO}_{3}(\mathrm{pH} 8.0)$. Twenty $\mu \mathrm{L}$ of Gibbs reagent $(1 \mathrm{mg} / \mathrm{ml}$ in ethanol) solution is added and the reaction mixture is agitated at room temperature for $45 \mathrm{~min}$ so that for full colour is developed. The absorbance of the reaction mixture is determined at $595 \mathrm{~nm}$ and converted to parts per million based on 2-HBP generated standard curve.

\subsection{GC/MS analysis}

JOEL-Q1000GC gas chromatograph/mass spectrometer with capillary column of HP190915-433 type $(30.0 \mathrm{~m} \times 250 \mathrm{~cm} \times 0.25 \mathrm{~cm})$ has been used with helium as carrier gas with a flow rate of $1.0 \mathrm{ml} / \mathrm{min}$ and split ratio of $20: 1$, the temperature of $250^{\circ} \mathrm{C}$ at injection port, El source, and ionization voltage of $70 \mathrm{eV}$ and temperature of $230^{\circ} \mathrm{C}$ at iron source. The temperature was $50{ }^{\circ} \mathrm{C}$ at initial pressure for 2 min and was increased to $300{ }^{\circ} \mathrm{C}$ at a heating rate of $10^{\circ} \mathrm{C} / \mathrm{min}$ and then kept for $10 \mathrm{~min}$.

\subsection{DBT degradation study}


The degradation activity of DBT through bacterial isolates of Ralstonia sp., Pesudoxanthomonas sp. and Rhodococcus sp. was studied in shake-flasks $(100 \mathrm{ml})$ using DBT in methanol as sole sulphur source in aqueous suspension of cells in Basal Salt medium. The flasks in triplicate were incubated for degradation of DBT.

\subsection{Metabolite extraction}

One $\mathrm{ml}$ of the aliquots (BSM + DBT + bacteria) was taken from medium to acidify up to $\mathrm{pH} \leq 2.0$ and same volume of ethyl acetate was added to it and the mixture was vortexed for $5 \mathrm{~min}$. After 5 min of phase separation, ethyl acetate phase was harvested. Extraction was repeated three times and all ethyl acetate phases were centrifuged (5000 rpm, $10 \mathrm{~min}$ ). The extracted ethyl acetate sample was analyzed by GC/MS JOEL-Q1000GC.

\section{Results And Discussion}

\subsection{Identification of DBT desulphurization bacterium}

The bacterial strains were identified by sequencing of 16S rRNA genes, identified at the 16S rRNA level and $99.8 \%$ similar to Ralstonia sp., Pseudoxanthomonas sp. and Rhodococcus sp. After purification and sub culturing of microorganism used for desulphurization of DBT, the growth was observed at OD $660_{\mathrm{nm}}$. After analysis of desulphurization, only Rhodococcus sp. is found to be more efficient to desulphurize organic sulphur. This could be due to the capacity of this bacterium to metabolize hydrophobic substrates (Monticello 2000).

\subsection{Growth properties of Rhodococcus sp., Ralstonia sp., Pseudoxanthomonas $s p$. in different concentration of Dibenzothiophene}

The growth profile of Ralstonia sp., Pseudoxanthomonas sp. and Rhodococcus sp. shows a short lag phase of growth followed by the exponential growth. The Maximum growth was observed in Rhodococcus sp. than other bacteria in 10 ppm DBT concentration. However, in the 15 ppm concentration, there was no growth in the bacterial cells (Fig. 1). This corroborates with the studies of Ohshiro et al. (1996) and Chen et al. (2008) who reported that low concentration of DBT enhances the bacterial growth while high concentration inhibits it because of the toxic effect of 2-HBP which is produced as a result of desulfurization of DBT.

\subsection{Utilization of DBT as the sole S-source or as C-source}

Gibbs's assay was performed by Gibbs's reagent (2, 6-dichloroquinone-4-chloroimine) (kayser et al. 1993) which is used for the determination of phenolic end products after desulphurization of DBT. Only one of the three isolates could produce blue color after one day of treatment in the form of 2-hydroxly biphenyl product while the rest could not. This indicates that only one isolate has the ability to desulphurize DBT 
into 2-HBP or phenolic products. The results is in agreement with those obtained by Gilbert et al. (1998), Wang and Krawiec (1994), Ansari (2008), Bhatia and Sharma (2010), and Rath et al. (2012).

\subsection{Desulfurization Profiles of Dibenzothiophene}

When growth density (OD $650 \mathrm{~nm}$ ) was compared among the three isolates, Rodococcus sp. was found to be most efficient throughout the incubation period (Fig. 1). The initial result of desulphurization is shown by the growth of Rhodococcus sp. in the growth medium in the broth. After treatment with Rhodococcus sp. there is a decrease in the concentration of DBT followed by accumulation of phenolic compounds in medium as confirmed by the production of permanent blue color in presence of Gibb's reagents. Rhodococcus sp. used DBT as sole S-source, although other isolates were able to desulfurize DBT to full fill their sulphur requirement. Comparison of bond strengths of $\mathrm{C}-\mathrm{C}$ to $\mathrm{C}-\mathrm{S}$ bond in thiophenes indicates that heteroatom bonds are weak in these molecules. Thus C-S bond is most susceptible to cleavage (Beskoski et al. 2008). HPLC analysis was performed to detect the intermediate metabolised product of DBT from the free cell culture supernatants of treated sample. The culture extracts revealed the presence of 2-HBP and DBTS. The desulphurized product of DBT i.e. 2-HBP appeared first after the lag phase of 20 hours and then the concentration continued to increase. Further, the chromatographs of treated sample were compared with the standard ones (Fig. 2a\&b). The data of desulphurization by Rhodococcus sp. strain was further confirmed by the HPLC profile of the desulfurized products. It clearly shows metabolism of DBT which desulfurized to 2-HBP as evidenced by the large peak of 2-HBP at RT1.435 (Fig. 3). On the other hand, the treatment of DBT with Pseudoxanthomonas sp. and Ralstonia sp. could not produce 2-HPB and there is complete removal of DBT (Fig. 4a\&b). This is confirmed by HPLC profile of metabolised product of DBT which does not show any peak of DBT in the chromatogram.

\subsection{GC/MS study of biodesulphurized end product}

The desulphurization activities were studies in medium containing DBT. Rhodococcus sp. could desulphurize $10 \mathrm{mg} / \mathrm{ml}$ of DBT at room temperature after 1 day of treatment (Fig. 5a). GC/MS analysis of the culture extracts in ethanol confirmed that the end product of DBT desulphurization pathway is 2-HBP. The detected metabolite of DBT desulphurization by Rhodococcus $\mathrm{sp}$. has a molecular mass ion (m/z) of 170 and its mass spectrum has a similarity to that of 2-HBP (Fig. 5b). This strain grew well in the medium containing $10 \mathrm{mg} / \mathrm{ml} \mathrm{DBT}$ as a sole sulphur source. Using GC/MS analysis another product in the broth was detected, and it was identified as 2-MBP (2-methoxybiphenyl) with mass ions (m/z) of 184 (Fig. 5c) which is converted from 2-HBP by methylation. As reported earlier, 2-HBP is toxic to bacterial cells and once the concentration of 2-HBP becomes high, the biodesulphurization of DBT is inhibited (Ohshiro et al. 1996 and Honda et al. 1998). The strain was grown in BSM medium with DBT as sole sulphur source to the stationary phase. The culture broth was acidified to $\mathrm{pH} 2.5$ and extracted with ethyl acetate. There was also production of intermediate compound, in order of DBT, DBTS (Dibenzothiophene sulfone), 2HBP + sulphate (Fig. 5d). This metabolic product is similar to other bacterial product which also has an ability to desulphurize DBT through selective cleavage of its $\mathrm{C}$-S bonds and by conserving its $\mathrm{C}-\mathrm{C}$ bonds (Izumi et al.1994; Olfield et al. 1997). Rhodococcus sp. Contains DszD enzyme, which is classified as an aromatic sulfinic acid hydrolase and may catalyse the following reaction (Oldfield et al.1997). 
$\mathrm{HBPS}+\mathrm{H}_{2} \mathrm{O} \rightarrow 2-\mathrm{HBP}+\mathrm{SO}^{2-}{ }_{3}+2 \mathrm{H}^{+}$

The GC/MS analysis of the extract shows four main peaks (retention time 19.6, 24.8, 29.65, 32.81), which are not observed in the extract prepared from cells grown on inorganic sulphate (Fig. 5e). The strains of Ralstonia sp. and Pseudoxanthomonas sp. were grown in BSM medium with DBT as the sole sulphur source and the extract did not generate 2-HBP and other products of desulphurization. The GC/MS study of the extract is indicative of complete consumption of the DBT by the bacterial cells (Fig. 6).

\section{Conclusions}

Based on the present investigation, following conclusions may be drawn:

1. Treatment of DBT with Rhodococcus resulted in a decrease in the concentration of DBT followed by accumulation of phenolic compounds in medium. This was confirmed by the production of permanent blue color in presence of Gibb's reagents. Rhodococcus sp. used DBT as sole S-source. The desulphurization was further confirmed by the HPLC profile of the desulfurized products. The metabolism of DBT which got desulfurized into 2-HBP was evidenced by large peak of 2-HBP at RT1.435. GC/MS analysis of the culture extracts in ethanol also supported the view that the end product of DBT desulphurization pathway is 2-HBP. There was also production of intermediate compound and this metabolic product is similar to other bacterial product which also can desulphurize DBT.

2. The treatment of DBT with Pseudoxanthomonas and Ralstonia sp. strains did not produce 2-HPB and other products of desulphurization but they completely degraded and removed DBT which confirmed by HPLC profile. The GC/MS study of the extract further indicates complete consumption of the DBT by the bacterial cells.

This study may be useful for the desulfurization of sulphur-rich coals from north-east India which contains varied proportions of organic sulphur.

\section{Declarations}

Acknowledgements

The authors thankfully acknowledge the University Grants Commission, New Delhi, India, for financial support in the form of DSK Post doctoral Fellowship Research Grant (No.F.4 - 2/2006 (BSR)/ES/1819/0031) for the study. The authors (ALS and PKS) acknowledge the Departments of Botany and Department of Geology, Banaras Hindu University respectively for the necessary facilities.

\section{References}

Ansari F (2008). Use of magnetic nanoparticles to enhance biodesulfurization', a thesis of Ph.D., Cranfield university, England. 
Ayhan D, Balat M (2004) Coal Desulfurization via Different Methods. Energy Sources 26:541-550. https://doi: 10.1080/00908310490429669.

Beskoski VP, Milic JB, Mandic M, Takic, Vrvic MM (2008) Removal of organically bound sulphur from oil shale by iron (III)-ion generated - regenerated from pyrite by the action of Acidithiobacillus ferrooxidansResearch on a model system. Hydrometallurgy 94:8-13.

Bhatia S, Sharma DK (2010) Biodesulfurization of dibenzothiophene, its alkylated derivatives and crude oil by a newly isolated strain Pantoea agglomerans D23W3. Biochemical Engineering Journal 50:104109. https://doi:10.1016/j.bej.2010.04.001.

Bhatia S, Sharma DK (2012) Thermophilic desulfurization of dibenzothiophene and different petroleum oils by Klebsiella sp. 13T. Environmental Science Pollution Research 19:3491- 3497. https://doi.org/10.1007/s11356-012-0884-2.

Borzenkova NV, Veselova IA, Shekhovtsova TN (2013) Biochemical methods of crude hydrocarbon desulfurization. Biology Bulletin Reviews 3:296-311. https://doi.org/10.1134/S20790 86413040026.

Chen H, Zhang WJ, Chen JM, Cai YB, Li W (2008) Desulfurization of various organic sulfur compounds and the mixture of DBT+4, 6-DMDBT by Mycobacterium sp. ZD-19. Bioresource Technology 99:36303634. https://doi.org/10.1016/j.biortech.2007.07.034.

Demirba SA (2002) Demineralization and desulfurization of coals via column froth flotation and different methods. Energy Conversion and Management 43:885-895. https://doi.org/10. 1016/S0 1968904(01)00088-7.

Furuya T, Kirimura K, Kino K, S Usami (2001) Thermophilic biodesulfurization of dibenzothiophene and its derivatives by Mycobacterium phlei WU-F1. FEMS Microbiology Letter 204:129-33.

https://doi.org/10.1111/j.1574-6968.2001.tb10875.x.

Gilbert SC, Morton J, Buchanan S, Oldfield C, McRoberts A (1998) Isolation of a unique benzothiophenedesulphurizing bacterium Gordona sp. strain 213E, and characterization of the desulphurization pathway. Microbiology UK 144:2545-2553. https://doi.org/10.1099/ 0022128 7-144-9-2545.

Gunam I, Yamamura K, Sujaya I, N Antara, Aryanta W, Tanaka M, Tomita F, Sone T, Asano K (2013) Biodesulfurization of dibenzothiophene and its derivatives using resting and immobilized cells of Sphingomonas subarctica T7b. Journal of Microbiology Biotechnology 23:473-82.

https://doi.org/10.4014/jmb.1207.07070.

Gundlach ER, Boehm PD, March M, Atlas RM, Ward DM, Wolfe DA (1983) The fate of Amoco Cadiz oil. Science 221:122-129. https://doi: 10.1126/science.221.4606.122.

Honda H, Sugiyama H, Saito I, Kobayashi T (1998) High cell density culture of Rhodococcus rhodochrous by $\mathrm{pH}$-stat feeding and dibenzothiophene degradation. Journal of Bioscience and Bioengineering 85:334- 
338. https://doi.org/10.1016/S0922-338X(97)85685-1.

Izumi Y, Oshiro T, Ogino H, Hine Y, Shimao M (1994) Selective desulfurization of dibenzothiophene by Rhodococcus erythropolis D-1. Applied Environmental Microbiology 60: 223-226.

Kayser KJ, Bielaga-Jones BA, Jackowski K, Odusan O, Kilbane J (1993) Utilization of Organo-Sulphur compounds by axenic and mixed cultures of Rhodococcus rhodochrous IGTS8. General Microbiology 139:3123-3129. https://doi.org/10.1099/00221287-139-12-3123.

Kilbane JJ (1990) Bio desulphurization Future Prospects in Coal Cleaning. Proceedings $7^{\text {th }}$ Annual International Pittsburgh Coal Conference pp. 373-381.

Kirimura K, Furuya T, Nishii Y, Yoshitaka I, Kino K, Usami S (2001) Biodesulfurization of dibenzothiophene and its derivatives through the selective cleavage of carbon-sulfur bonds by a moderately thermophilic bacterium Bacillus subtilis WU-S2B. Bioscience Bioengineering 91:262-266.

https://doi.org/10.1016/S1389-1723(01)80131-6.

Kumar A, Singh AK, Singh PK, Singh AL, Saikia BK, Kumar A (2019) Desulfurization of Giral lignite of Rajasthan (Western India) using Burkholderia sp. GR 8- 02. International Journal of Coal Preparation and Utilization. https://doi:10.1080/19392699.20 19.1651721.

Luo MF, Xing JM, Gou ZX, Li S, Liu HZ, Chen JY (2003) Desulfurization of dibenzothiophene by lyophilized cells of Pseudomonas delafieldii R-8 in the presence of dodecane. Biochemical Engineering Journal 13:1-6. https://doi.org/10.1016/S1369-703X(02)00 078-5.

Max Nestler FH (1974) Characterization of wood-preserving coal-tar creosote by gas-liquid chromatography. Analytical Chemistry 46:46-53.

Mishra S, Pradhan N, Panda S, Akcil A (2016) Biodegradation of dibenzothiophene and its application in the production of clean coal. Fuel Processing Technology 152:325-342.

https://doi.org/10.1016/j.fuproc.2016.06.025.

Mishra S, Panda PP, Pradhan N, Satapathy D, Subudhi U, Biswal SK, Mishra BK (2014) Effect of native bacteria Sinomonas flava 1 C and Acidithiobacillus ferrooxidans on desulphurization of Meghalaya coal and its combustion properties. Fuel 117:415-421. https://doi.org/10.1016/j.fuel.2013.09.049.

Mohebali G, Ball AS, Rasekh B, Kaytash A (2007) Biodesulfurization potential of a newly isolated bacterium, GordoniaalkanivoransRIPI90A. Enzyme Microbiology Technology 40:578-584. https://doi.org/10.1016/j.enzmictec.2006.05.012.

Monticello DJ (2000) Biodesulfurization and the upgrading of petroleum distillates. Current Opinion in Biotechnology 11:540-546. https://doi.org/10.1016/S0958-1669(00)00154-3. 
Nekozuka S, Nakajimakamze T, Nomura N, Lu J, Nakahara T (1997) Specific desulfurization of dibenzothiophene by Mycobacterium sp. G3. Biocatalysis and Biotransformation 15:17-27. https://doi.org/10.3109/10242429709003607.

Ohshiro T, Izumi Y (1999) Microbial desulfurization of organic sulphur compounds in petroleum. Bioscience Biotechnology Biochemistry 63:1-9. https://doi.org/10.1271/bbb.63.1.

Ohshiro T, Suzuki K, Izumi Y (1996) Regulation of dibenzothiophene degrading enzyme activity of Rhodococcus erythropolisD-1. Fermentation Bioengineering 81:121-124. https://doi.org/10.1016/0922338X(96)87588-X.

Oldfield C, Pogrebinsky O, Simmonds J, Olson ES, Kulpa CF (1997) Elucidation of the metabolic pathway for dibenzothiophene desulfurization by Rhodococcus sp. strain IGTS8 (ATCC53968). Microbiology 143:2961-2973. https://doi.org/10.1099/00221287-143-9-2961.

Ollivier B, Magot M (2005) Petroleum microbiology USA: Blackwell. pp. 239-252.

Rath K, Mishra B, Vuppu S (2012) Biodegrading ability of Organo-Sulphur compound of a newly isolated microbe Bacillus sp. KS1 from the oil contaminated soil. Archives of Applied Science Research 4:465-471.

Rhee SK, Chang JH, Chang YK, Chang HN (1998) Desulfurization of dibenzothiophene and diesel oils by a newly isolated Gordona strain CYKSI. Applied Environmental Microbiology 64:2327-2331.

Singh AL, Singh PK, Kumar A, Singh MP (2012) Desulfurization of selected hard and brown coal samples from India and Indonesia with Ralstonia sp. and Pseudoxanthomonas sp. Energy Exploration and Exploitation 30:985-998. https://doi.org/10.1260/0144-5987.30.6.985.

Singh AK, Kumar A, Singh PK, Singh AL, Kumar A (2018) Bacterial desulphurization of low rank coal: A Case Study of Eocene Lignite of Western Rajasthan, India. Energy Sources Part A: Recovery, Utilization, and Environmental Effects 40:1199-1208. https://doi.org/ 10.1260/0144-5987.30.6.985.

Singh PK, Singh AL, Kumar A, Singh MP (2013) Control of different pyrite forms on desulfurization of ' coal with bacteria. Fuel 106:876-879. https://doi.org/10.1016/j.fuel.2012.1 1.002.

Singh PK, Singh AL (2010). Desulfurization and demineralization of coal with bacteria: An ecofriendly concept for clean coal energy. In V. Bajpai, P. Sharma \& V.K. Gupta (Eds). Recent Trends in Microbial Biotechnology, p 215-231; Lambert Academic Publishing, Germany ISBN No-987-3-8433-9002-6.

Soleimani M, Bassi A, Margaritis A (2007) Biodesulfurization of refractory organic sulphur compounds in fossil fuels. Biotechnology Advances 25:570-596. https://doi.org/10.1016/j. biotech adv.2007.07.003.

Tailleur RG, Ravigli J, Quenza S, Valencia N (2005) Catalyst for ultra-low sulphur and aromatic diesel. Applied Catalysis A-General 282:227-235. https://doi.org/10.1016/j.apcata.200 4.12.014. 
Wang P, Krawiec S (1994) Desulfurization of dibenzothiophene to 2-hydroxybiphenyl by some newly isolated bacterial strains. Archives of Microbiology 161:266-271. https://doi.org/ 10.1007/BF00248703.

Zhang M, Yue J, Yang YP, Zhang H, Lei J, Jin R, Zhang X, Wang H (2005) Detection of mutations associated with isoniazid resistance in Mycobacterium tuberculosis isolates from China. Journal of Clinical Microbiology 43:5477-5482. https://doi.org/10.1007/BF002487 03.

\section{Figures}

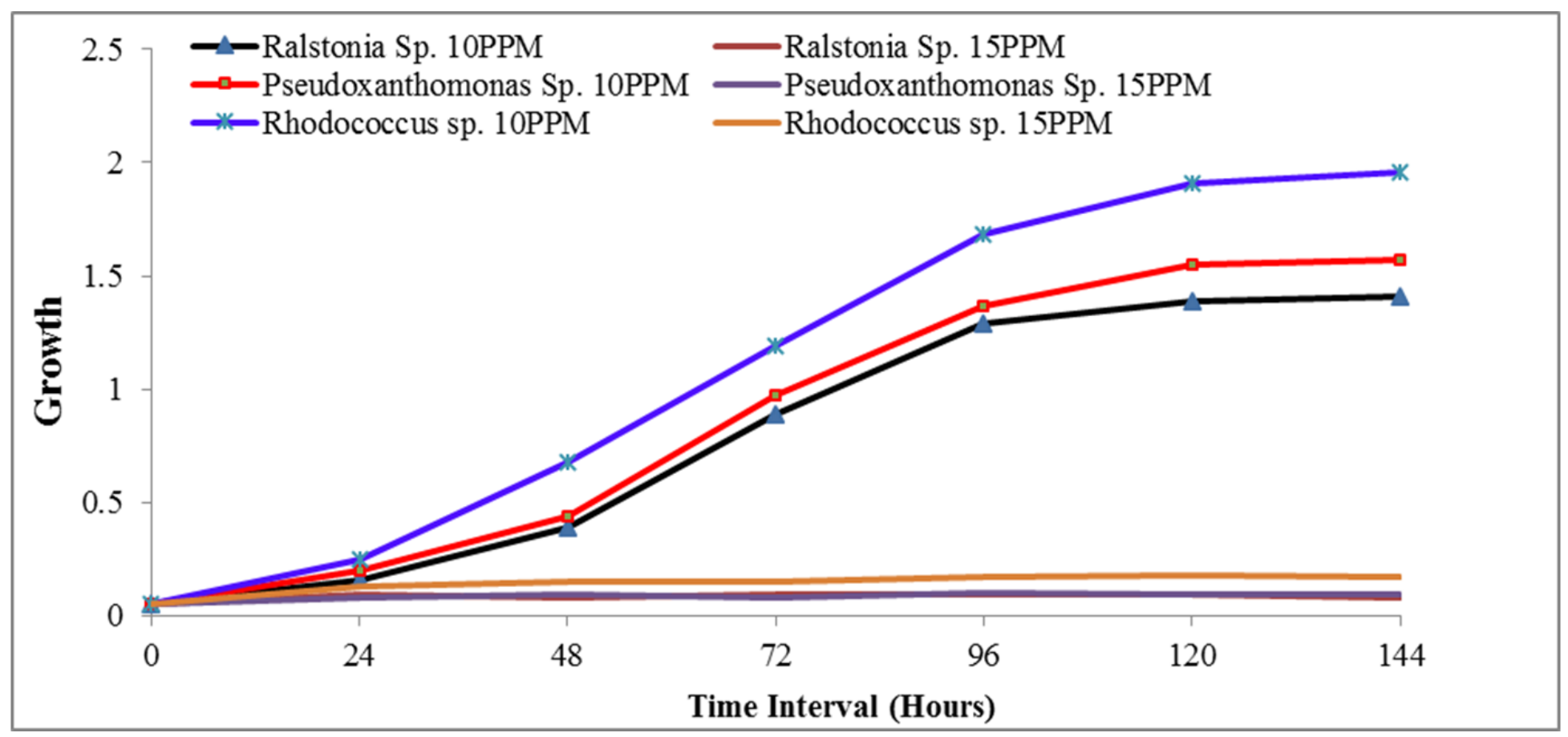

Figure 1

Comparative studies of growth profile by different bacteria in presence of Dibenzothiophene. 


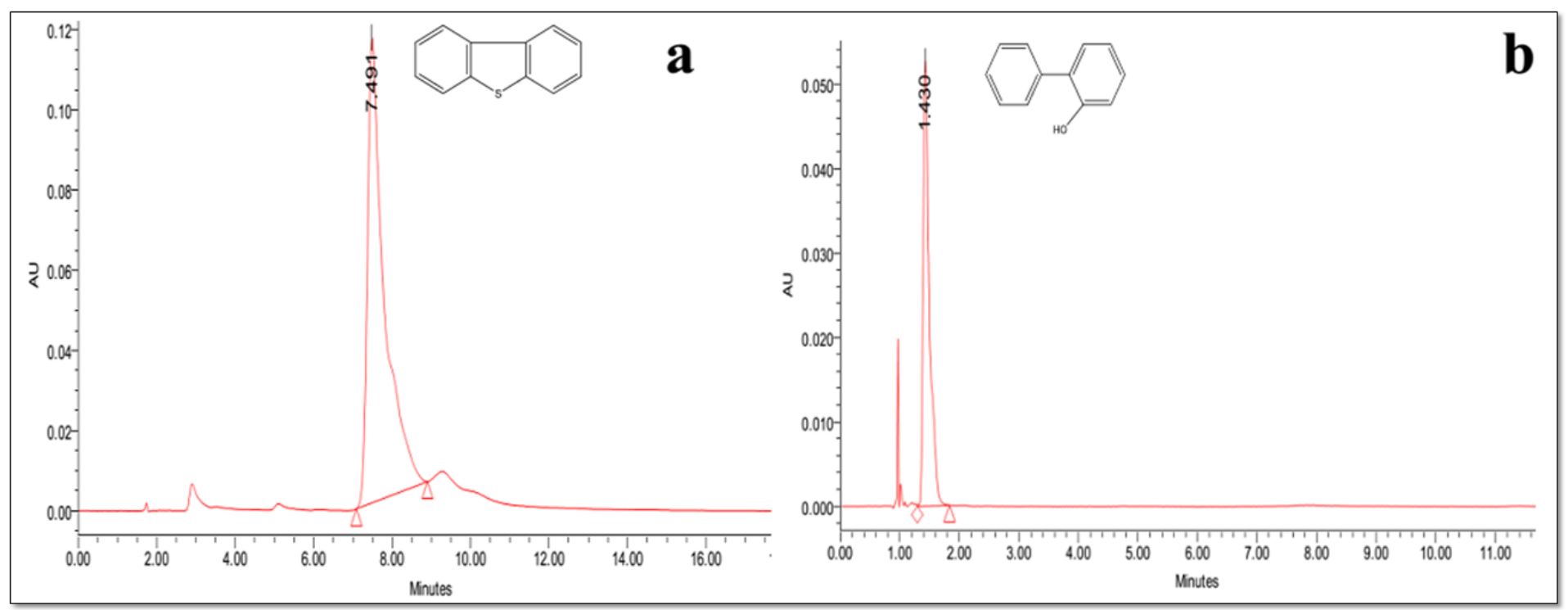

\section{Figure 2}

(a) HPLC chromatogram of DBT and (b) chromatogram of 2- HBP.

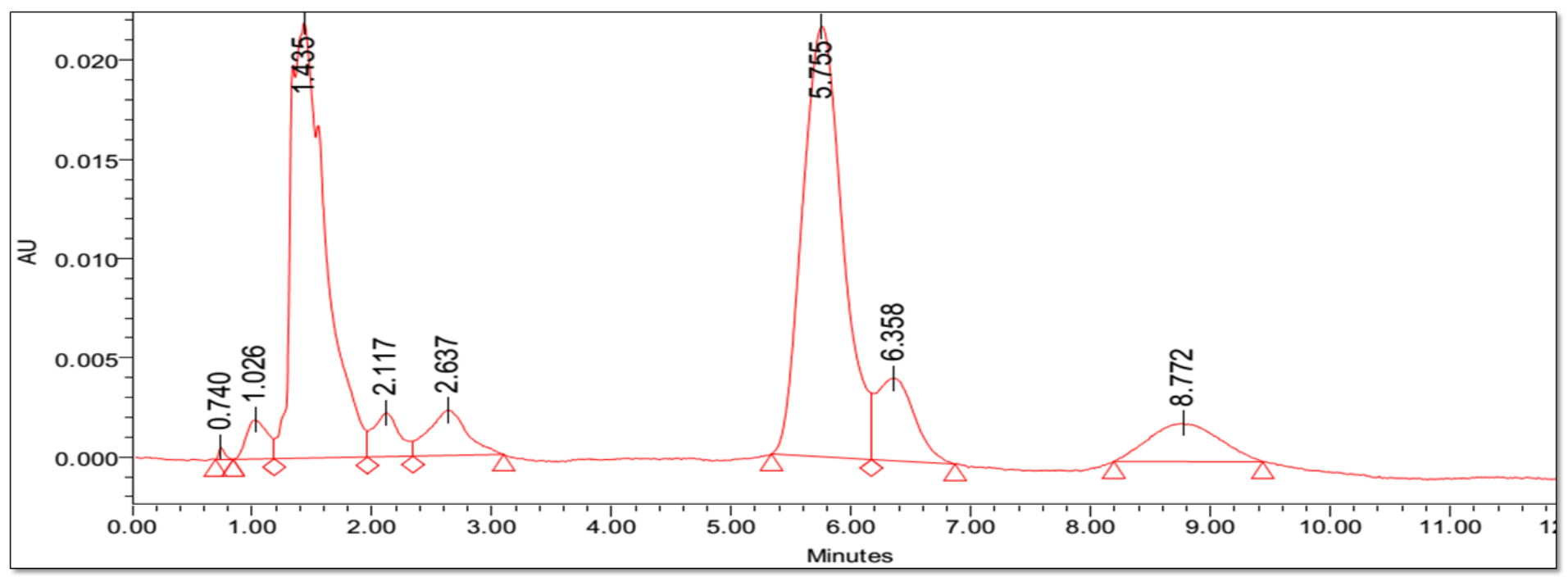

Figure 3

HPLC chromatogram showing desulfurization of DBT after 1 day of treatment with Rhodococcus sp. 

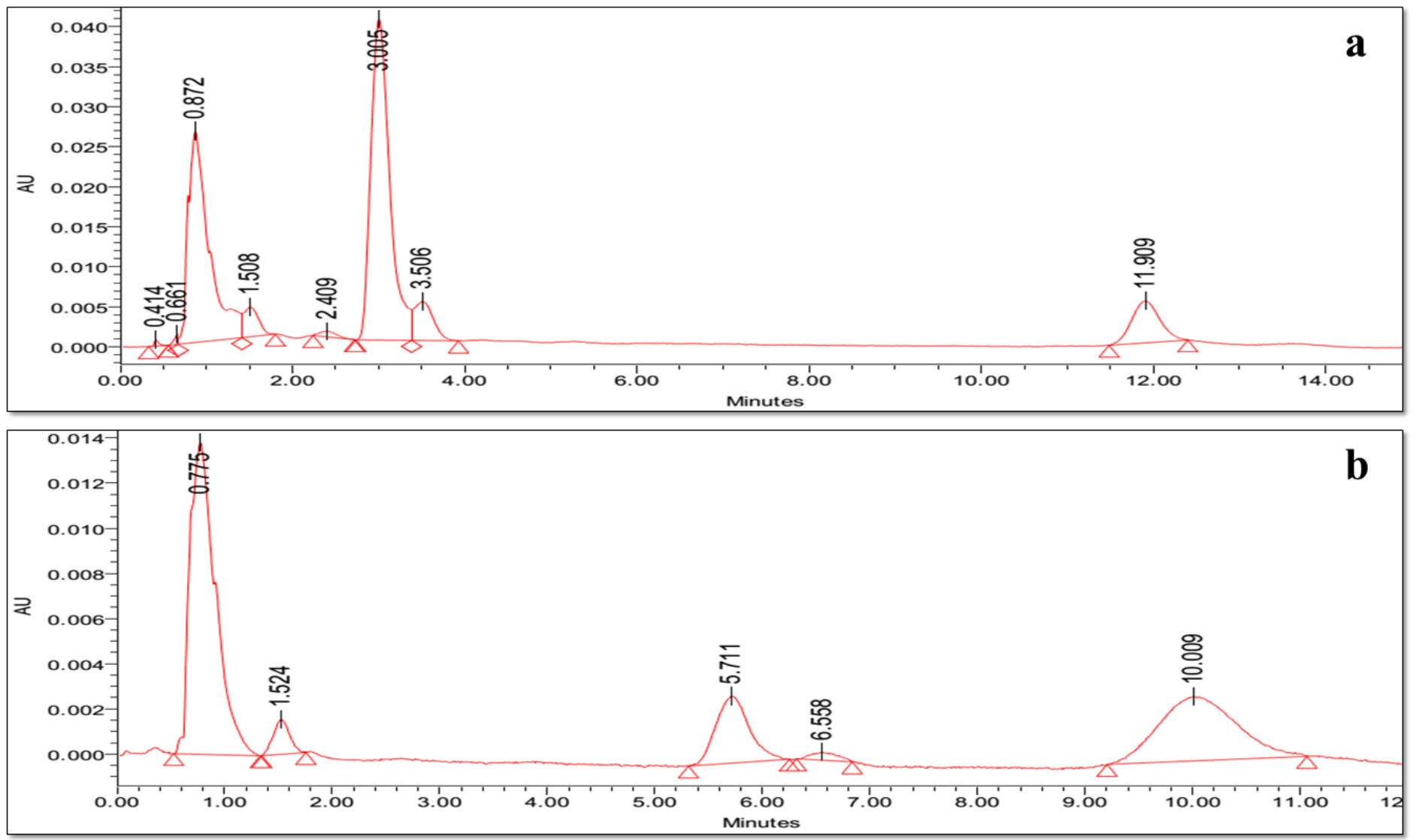

\section{Figure 4}

Utilization of DBT as a Source of Carbon by Ralstonia sp. (a) and Pseudoxanthomonas sp. (b). 

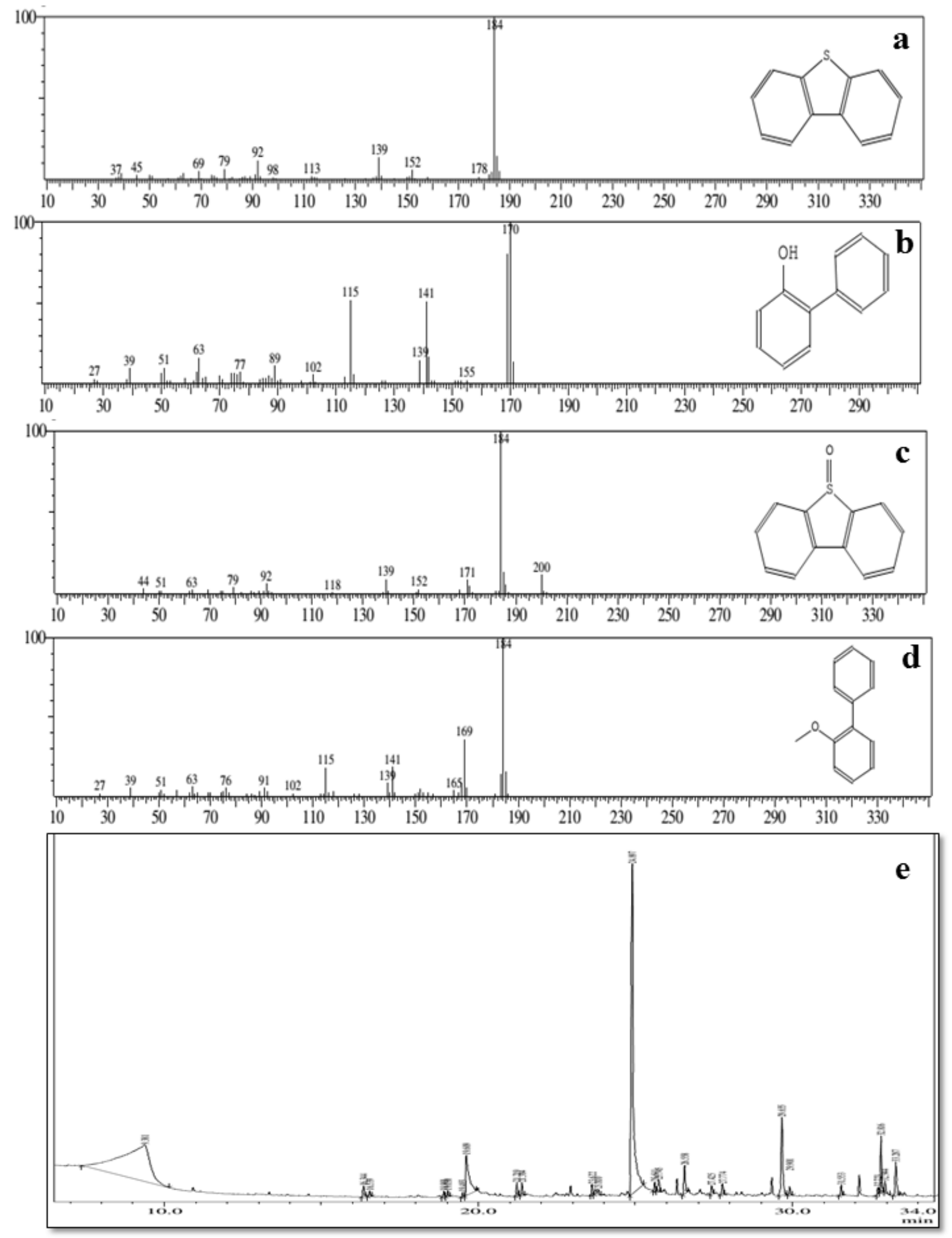

\section{Figure 5}

Mass spectrogram of the metabolite formed in the degradation of 10ppm of dibenzothiophene DBT by Rhodococcus sp. a) Mass spectrum of DBT(m/z-184); b) Mass spectrum of 2-HBP (m/z-170);c) c) Mass spectrum of Dibenzothiophene monoxygenase (m/z-184); d) Mass spectrum of 2-methoxy-3,3-dimethylbiphenyl (m/z-184); e) Total GC Chromatography of the culture extract of Rhodococcus sp. 

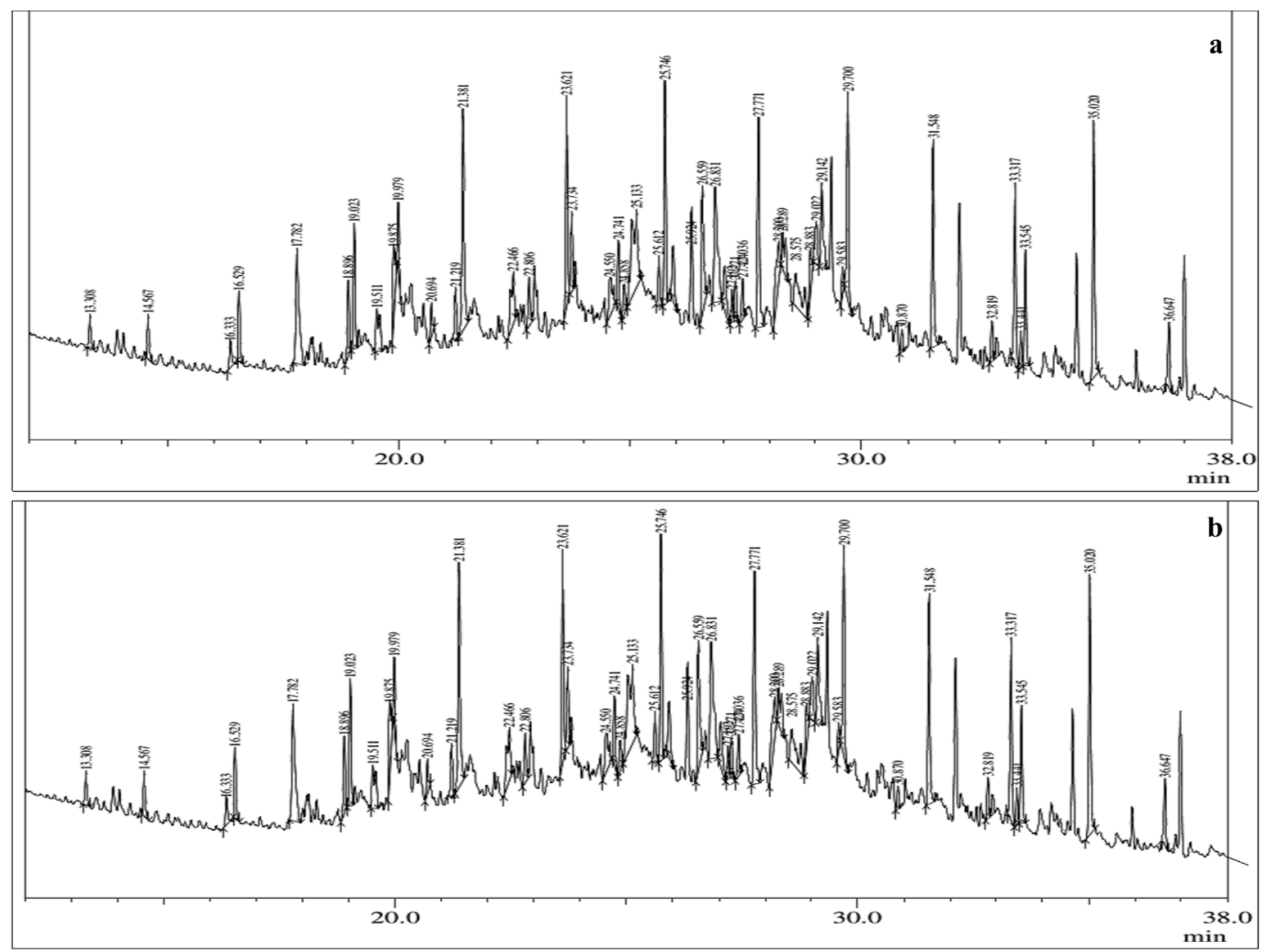

Figure 6

Total GC chromatography of the culture extract of Ralstonia sp. and Pseudoxanthomonas sp. 